\title{
THE CONCEPT OF RELATIONSHIP BETWEEN INDIVIDUAL ATTRIBUTES AND INTENTIONS OF POTENTIAL RURAL ENTREPRENEURS IN AQUACULTURE INDUSTRY
}

\author{
Nurul Najida Ab Rahim ${ }^{1}$ \\ Faculty of Entrepreneurship and Business, \\ Universiti Malaysia Kelantan, Malaysia \\ (Email: nurulnajida@gmail.com) \\ Anis Amira Ab Rahman 2 \\ Faculty of Entrepreneurship and Business, \\ Universiti Malaysia Kelantan, Malaysia \\ Mohd Asrul Hery Ibrahim ${ }^{3}$ \\ Faculty of Entrepreneurship and Business, \\ Universiti Malaysia Kelantan, Malaysia
}

Accepted date: $14-10-2018$

Published date: 08-07-2019

To cite this document: Rahim, N. N. A., Rahman, A. A. A., \& Ibrahim, M. A. H. (2019). The Concept of Relationship Between Individual Attributes and Intentions of Potential Rural Entrepreneurs in Aquaculture Industry. International Journal of Entrepreneurship and Management Practices, 2(6), 16-22.

DOI: $10.35631 / \mathrm{IJEMP} .26002$

\begin{abstract}
The objective of this paper is to examine and contribute a better understanding of individual attribute and potential rural entrepreneur intention toward involvement in the aquaculture sector. The previous study on potential rural indicates the challenges of rural development in terms of sustaining communities and attracting tourists. Thus, this paper intends to fill in the gaps within the boundary of rural attributes in the entrepreneurship's sustainability. Quantitative research methodology has been adopted to achieve this goal. Data were collected by using research instruments of questionnaire participated by 200 respondents in a rural area in Kelantan. Statistical analysis used with SPSS tools. As part of the paper, the sustainability performance of potential rural entrepreneurs in the aquaculture industry also is highlighted. Study on aquaculture that regards to the entrepreneurship intervention programs is still scarce as most of them depend on social security such as government aid to lead their life.
\end{abstract}

Keywords: Individual, Intentions, Potential Rural, Entrepreneur

\section{Introduction}

Rural entrepreneurs are vital in economic development of the countries (Henderson, 2002). However, the entrepreneurship field nowadays still in the lower stage of acknowledgement as 
the main source of economic development among rural (Meccheri \& Pelloni, 2006). The social entrepreneurs role influence the engagement of rural entrepreneurs in ventures which not only motivated the involvement in business due to profit, but also because of social objectives (Mottiar, Boluk, \& Kline, 2018). The government should encourage the potential rural entrepreneurs to start up new venture by disclose them toward microfinance facilities (Dutta \& Banerjee, 2018).

Poverty in developing country increased due to downturn economy crisis in worldwide concern. Poverty differences cut across gender, ethnicity and income source. In the community, the rural is poor more than the urban community. Poverty became an obstacle to achieve sustainable development and wellbeing of people.

Other than that, rural entrepreneurs were asset for the development of economic in our country whereas their huge contributions were signified. The unemployment among rural automatically impacted the states in Malaysia. As indicated by Department of Statistics of Malaysia (DOSM) and Economy Planning Units (EPU) of Jabatan Perdana Menteri, Kelantan is the highest state $(0.4$ per cent $)$ that their communities extremely poor after Perlis which is 0.6 per cent on 2014 ((EPU), 2014). Other than that, the major problem is rural people cannot excel due to lack of many factor such as knowledge, unaware of technology development and marketing skill (Saxena, 2012). Most of the villagers are coming from poor family that doesn't have fixed income. They are too striving to lead their family life.

In brief, the aquaculture industry is stress on nurturing entrepreneur's spirit among rural people due to employment opportunities and easy to be practice. This industry is one of the initiatives by the government in aiding the rural communities in poverty eradication, and indirectly increased the supply of the fish and food production in the country. The intention will rely on the willingness of entrepreneurs to invest in new venture while start up a business (Sajjad, Shafi, \& Dad, 2012).

\section{Problem Statement}

The insufficient capital and money caused the rural face problem to setup new venture. It influences the rural intention to involve in entrepreneurship field. In overall, due to poor social wellbeing in term of entrepreneurship knowledge, marketing techniques, and inadequate capital to joint venture, it automatically cause the current status of rural people are remain lower. Despite of that, sometimes they are left behind compare to urban people.

Intention is necessary when the individual or employees are willing to performing up to a definite standard. The entrepreneurial process can be considerate on the part of individual and the opportunity identification based upon individual intention (Engle et al., 2010). The rural intention toward aquaculture involvement can be recognize very differently for any given individual's behaviour. It can be analyse through rural entrepreneur action in behaviour (Engle et al., 2010). The individual attributes among rural have relation with intention to involve in the aquaculture industry as their effort in raising the current socio-economic level. Institutions and individuals promoting rural development now see entrepreneurship as the sources to generate income.

\section{Objectives}

Based on the problem statement, it is indicated that there is less of the study on the intention of potential rural entrepreneurs to involve in aquaculture industry due to inadequate of 
knowledge, capital and skills. Therefore, the main objective of this research is to examine the relationship of individual attributes and intention of potential rural entrepreneurs to involved in the aquaculture industry.

\section{Literature Review}

\section{Aquaculture Industry and Definition}

The expansion of aquaculture industry in Malaysia has created a significant effect for rural livelihoods as most of their dependent on the fishery sector (Hamdan, Othman, \& Kari, 2015). This industry vital in poverty eradication and upgrade the livelihoods of communities especially in rural areas (Hamdan et al., 2015). Aquaculture defined as the farming and agriculture of aquatic creatures under-controlled or semi-controlled circumstances (Harrell, 1914). Meanwhile, Lehane (2013) described aquaculture as the breeding and harvesting of aquatic organisms in marine or freshwater's conditions. They are several of program or initiatives of Malaysia Government to spearhead the aquaculture industry included Malaysian Good Agricultural Practices (MyGAP) scheme and rural tourism. MyGAP stressed on the agricultural, aquaculture and livestock sector which organized to generate income of rural people throughout this industry ((MOA), 2016). Meanwhile, the rural tourism among the one agenda by the government to build up the job opportunities and eliminate poverty among rural communities (Amir, Ghapar, Jamal, \& Ahmad, 2015).

In addition, regarding to the expansion of aquaculture industry, Gyunghoon Kim, Lauren N. Duffy, Jodice, and Norman (2017) agreed with the statement by National Marine Fisheries Service (2015) that indicated almost one-half of the world's seafood consumption comes from aquaculture production of fish and shellfish. It show that aquaculture sector have potential to grow as supportable income in future (Gjedrem, Robinson, \& Rye, 2012). Besides, the sector has become an important mechanism for helping meet the increasing demand for seafood which declared by Washington and Ababouch (2011). The rural who intend to involve in aquaculture need to portray the potential solution of the problem regarding health and safety concerns that related to pollutants within aquaculture sector (Gyunghoon Kim et al., 2017; Schlag, 2010).

The aquaculture offers great scope for technical innovation to further increase resource efficiency due to this sector relatively young compared with terrestrial livestock sectors (Subasinghe, Curry, McGladdery, \& Bartley, 2003; Waite et al., 2014). Thus, improving the productivity aquaculture and ensuring it provides safe, affordable, and nutritious food to millions of people around the world is an important item for a sustainable food future (Waite et al., 2014). Unfortunately, due to lower knowledge in technology and innovation, it become a scarcity for rural in developing country like Malaysia to successfully make the sector as sustainable primary income within definite time. In overall, new technology usually come from the world's largest economy such as US and China. Thus, the rural in developing country are only exposed to the modification knowledge of the sector as their source of income and not in innovation.

\section{Intention of Rural}

Intention is a necessary condition to being an entrepreneur and carry out specific behaviour by rural (Kuckertz \& Wagner, 2010). According to Ajzen (1991), the person's attitudes towards that behaviour is depended by their intention in carrying out a given act (Liñán, 2004). A more positive attitude would increase the intention of carrying it out. It means that the rural 
might perform their task confident and hardly if they are enjoying it. In summarize, it show that intention becomes the fundamental element towards explaining behaviour which intention itself indicates the effort that the person will make to carry out that behaviour (Ajzen, 1991; Liñán, 2004). The motivations of these 'new entrepreneurs' are quite different, since they are individuals who own and operate a business without focusing mainly on profits (Pato \& Teixeira, 2013). Nowadays, the rural seem agree with government initiatives in aquaculture sector as they see the entrepreneurship as lifestyle and easy to adapt in daily life.

Regarding the intention of rural to involve in aquaculture sector, basically the new entrepreneurs are facing problem because they are lacking raw material and the source of capital. It is quite difficult to make availability of raw materials all the time in rural areas due to poor road connectivity and poor transportation by rural (Haggblade, Hazell, \& Reardon, 2010). Availability of raw materials is an essential component of entrepreneurship due to the price are very high (Mishra \& Kiran, 2014). Therefore, the entire problems become possible with government support in term of money and training.

\section{Theoretical Framework}

\section{Fishery Social Impact Assessment (SIA) Model}

The determination of entrepreneurial intentions can be advocated through demographic, family background and experience, while the rural's intent to involve in aquaculture sector related to entrepreneurship may be explained by Fishery SIA Model (Pollnac et al., 2006).

\section{Individual Attributes}

According to Pollnac et al. (2006), there are various factors that indicate the individual attributes. Among the factors are participant characteristics, personality traits, resilience of individual and demographic factors. Meanwhile, the researcher briefly used questions on age, gender, years of education, area of residence (rural or urban), and subjective social class, in order to control for each individual's socio-economic background as highlighted by Mayda (2004). Apart from that, according to declaration by Hainmueller and Hiscox (2006), Scheve and Slaughter comprised the importance of human capital or skills. They underlined that the individuals with lower skills were more likely have intention to support restrictions on imports than those with higher skills based on examining data from recent American National Election Studies (NES) surveys in the United States. Meanwhile, according to Pollnac et al. (2006), the individual and social resilience are complicated variables that represent an intention or ability to cope with change. Besides that, a boundless study by Apostle et al (1985); Pollnac and Poggie (1988); Gatewood and McCay (1990) ; Binkley (1995); Pollnac et al. (2001) briefly connected intention of the job to individual attributes such as mental health and longevity (Pollnac et al., 2006).

In summarize the figure 1 below show the relationship of individual attributes with the intention of potential rural entrepreneur to involve in aquaculture.

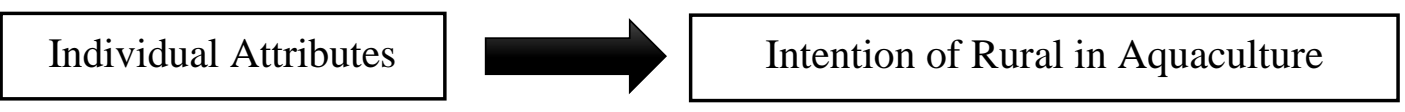

Figure 1: Conceptual Model 


\section{Methodology}

Two hundred respondents were involved in the study. To eliminate the common responses biases, the respondents were chosen purposively from the listed name which is registered under Kelantan Islamic Religious Council (MAIK). The selected portential rural entrepreneurs were defined as bottom forty percent who have monthly income in the range below of RM2500. The selected areas for the study are Tumpat, Bachok, Jeli and Gua Musang. This research adopted the quantitative approach throughout questionnaire as their means of collecting the data.

\section{Conclusion and Suggestion}

Hence, based on review of the study, it specified that person can act upon intention if only if he is having control toward manners. It shows positive significant relationship between individual attributes with the intention of potential rural entrepreneurs to involve in aquaculture sector. Therefore, the dependent variable (intention of rural involved in aquaculture) is well linked to Fishery SIA model. This paper has revealed the rural intention in entrepreneurial as a distinct phenomenon through their performing behaviour. The intention has important implication for rural who have opportunity to be guide and influence their career choices.

This study also show that the aquaculture sector has potential to grow up based on Malaysia current economic. In summarize of this paper, rural' $s$ knowledge and attitude about aquaculture would be predictors of their inferior success. By involving aquaculture industry systematically, the rural peoples have the potential to own future bright, and then upgrade their level of thinking and living. We suggest the government and non-government agencies (eg: Malaysian Fisheries Development Board (LKIM), Kemubu Agriculture Development Authorities (KADA), TEKUN National) have two way communication and connection with rural in exposing them the way to act and guide them. Besides, in involving aquaculture sectors, the rural also need to be disclosed with potential risk that they might face in future. They are advisable to open minded in accepting any possible consequences in future and act as risk taker just like many of successful people, including Bill Gates and Michael Dell whom achieved their success by taking the risk of launching their own ventures.

\section{Acknowledgement}

This paper is a part of on-going research at Master level. This research was funded by the Ministry of Higher Education, Malaysia under the grant entitled "Developing Entrepreneurship Training Programme through the Rural Entrepreneurship Model (REMODE) for Aquaculture Industry (R/NRGS/A01.00/280A/004/2014/000153)”.

\section{References}

(EPU), J. P. M. D. d. U. P. E. (2014). Kadar kemiskinan dan kemiskinan tegar mengikut negeri dan strata, 2012 dan 2014.

(MOA), M. o. A. a. A.-b. I. M. (2016). MyGAP (Malaysian Good Agricultural Practices). from http://www.moa.gov.my/en/mygap

Ajzen, I. (1991). The theory of planned behavior. Organizational behavior and human decision processes, 50(2), 179-211.

Amir, A. F., Ghapar, A. A., Jamal, S. A., \& Ahmad, K. N. (2015). Sustainable tourism development: A study on community resilience for rural tourism in Malaysia. Social and Behavioral Science, 116, 116-122. 
Dutta, A., \& Banerjee, S. (2018). Does microfinance impede sustainable entrepreneurial initiatives among women borrowers? Evidence from rural Bangladesh. Journal of Rural Studies, 60, 70-81.

Engle, R. L., Dimitriadi, N., Gavidia, J. V., Schlaegel, C., Delanoe, S., Alvarado, I., . . . Wolff, B. (2010). Entrepreneurial intent: A twelve-country evaluation of Ajzen's model of planned behavior. International Journal of Entrepreneurial Behavior \& Research, 16(1), 35-57.

Gjedrem, T., Robinson, N., \& Rye, M. (2012). The importance of selective breeding in aquaculture to meet future demands for animal protein: a review. Aquaculture, 350, 117-129.

Gyunghoon Kim, Lauren N. Duffy, Jodice, L. W., \& Norman, W. C. (2017). Coastal Tourist Interest in Value-Added, Aquaculture-Based, Culinary Tourism Opportunities. Coastal Management, 45. doi: 10.1080/08920753.2017.1327345

Haggblade, S., Hazell, P., \& Reardon, T. (2010). The rural non-farm economy: Prospects for growth and poverty reduction. World Development, 38(10), 1429-1441.

Hainmueller, J., \& Hiscox, M. J. (2006). Learning to Love Globalization: Education and Individual Attitudes Toward International Trade. International Organization doi: I0. I0I7/S0O2081830606U14O

Hamdan, R., Othman, A., \& Kari, F. (2015). CLIMATE CHANGE EFFECTS ON AQUACULTURE PRODUCTION PERFORMANCE IN MALAYSIA: AN ENVIRONMENTAL PERFORMANCE ANALYSIS. International Journal of Business \& Society, 16(3).

Harrell, R. M. (1914). What is Aquaculture? Maryland Institute for Agriculture and Natural Resources.

Henderson, J. (2002). Building the rural economy with high-growth entrepreneurs. Economic Review-Federal Reserve Bank of Kansas City, 87(3), 45.

Kuckertz, A., \& Wagner, M. (2010). The influence of sustainability orientation on entrepreneurial intentions-Investigating the role of business experience. Journal of business venturing, 25(5), 524-539.

Lehane, S. (2013). Fish for the Future: Aquaculture and Food Security.

Liñán, F. (2004). Intention-based models of entrepreneurship education. Piccolla Impresa/Small Business, 3(1), 11-35.

Mayda, A. M. (2004). Who Is Against Immigration? A Cross-Country Investigation of Individual Attitudes toward Immigrants.

Meccheri, N., \& Pelloni, G. (2006). Rural entrepreneurs and institutional assistance: an empirical study from mountainous Italy. Entrepreneurship \& Regional Development, 18(5), 371-392.

Mishra, G., \& Kiran, D. U. V. (2014). Rural Women Entrepreneurs: Concerns \& Importance. International Journal of Science and Research (IJSR), 3(9).

Mottiar, Z., Boluk, K., \& Kline, C. (2018). The roles of social entrepreneurs in rural destination development. Annals of Tourism Research, 68, 77-88.

Pato, M. L., \& Teixeira, A. A. C. (2013). Twenty Years of Rural Entrepreneurship: A Bibliometric Survey. FEP Working Paper.

Pollnac, R. B., Abbott-Jamieson, S., Smith, C., Miller, M. L., Clay, P. M., \& Oles, B. (2006). Toward a Model for Fisheries Social Impact Assessment. Marine Fisheries Review.

Sajjad, S. I., Shafi, H., \& Dad, A. M. (2012). Impact of culture on entrepreneur intention. Information Management and Business Review, 4(1), 30.

Saxena, S. (2012). Problems faced by rural entrepreneurs and remedies to solve it. IOSR Journal of Business and Management (IOSRJBM), 3(1), 23-29. 
Schlag, A. K. (2010). Aquaculture: an emerging issue for public concern. Journal of Risk Research, 13(7), 829-844.

Subasinghe, R. P., Curry, D., McGladdery, S. E., \& Bartley, D. (2003). Recent technological innovations in aquaculture. FAO Fisheries Circular, 886, 85.

Waite, R., Beveridge, M., Brummet, R., Castine, S., Chaiyawannakarn, N., Kaushik, S., . . . Philips, M. (2014). Improving Productivity and Environmental Performance of Aquaculture

Washington, S., \& Ababouch, L. (2011). Private standards and certification in fisheries and aquaculture: current practice and emerging issues. FAO fisheries and aquaculture technical paper (553), I. 